\title{
EFEKTIVITAS PEMBELAJARAN TEMATIK INTEGRATIF BERBASIS MULTIPLE INTELLIGENCE DAN HASIL BELAJAR SISWA PADA TEMA TUMBUHAN DAN HEWAN
}

\author{
${ }^{1}$ Yulia Pramusinta, ${ }^{2}$ Chindy Ema Elvianah, ${ }^{3}$ Tiara Anggraini Maghfiroh \\ ${ }_{1,2,3}$ Universitas Islam Lamongan \\ e-mail: 1yuliapramusinta@unisla.ac.id, ${ }^{2}$ ndyanaelviana@gmail.com, \\ 3tiaraam08@gmail.com
}

\begin{abstract}
The 2013 curriculum is a competency-based curriculum designed to anticipate 21st century competency needs. In this century, as we can witness together, the ability of creativity and communication will be very important. Intelligence in processing a science is an important thing to do, one of which is to sharpen multiple intelligences in students to produce a maximum student achievement, especially in thematic learning. The purpose of this study was to examine the effect of thematic learning and multiple intelligence on student learning outcomes. This research is an experimental quantitative research, this research was conducted on science class 5 subjects on the theme of plants and animals. The subjects in this study were 25 students. When this research was conducted in January-February 2017. The instrument used for data collection was the questionnaire / questionnaire method. Testing the credibility of the instrument using the instrument validity and reliability test. Data collection procedures in this study used observation, questionnaires / questionnaires and documentation. The data analysis technique of this study uses multiple linear regression analysis. The results showed there was a significant influence between integrative thematic learning and multiple intelligence in improving student learning outcomes.
\end{abstract}

Keywords: efektivitivity, Tematik Integratif, Multiple Intelligence, Learning Outcomes.

\section{A. Pendahuluan}

Kurikulum 2013 adalah kurikulum berbasis kompetensi yang dirancang untuk mengantisipasi kebutuhan kompetensi Abad 21. Pada abad ini, sebagaimana dapat kita bersama saksikan, kemampuan kreativitas dan komunikasi akan menjadi sangat penting. Sejalan dengan itu, rumusan kompetensi sikap, pengetahuan, dan keterampilan yang dipergunakan dalam Kurikulum 2013 mengedepankan pentingnya kreativitas dan komunikasi. Sejalan dengan itu, kompetensi yang diharapkan dari seorang lulusan $\mathrm{SD} / \mathrm{MI}$ dirumuskan sebagai memiliki kemampuan pikir dan tindak yang produktif dan kreatif dalam ranah abstrak dan konkret. Kemampuan tersebut diperjelas dalam kompetensi inti yang salah satunya adalah menyajikan pengetahuan dalam bahasa yang jelas, logis dan sistematis, dalam karya yang estetis, atau dalam tindakan yang mencerminkan perilaku anak sehat, beriman, berakhlak mulia. Kompetensi tersebut dirancang untuk dicapai melalui proses pembelajaran berbasis penemuan (discovery learning) melalui kegiatan-kegiatan berbentuk tugas (project based learning) yang 
mencakup proses-proses mengamati, menanya, mencoba, menalar, dan mengkomunikasikan. Pembelajaran tematik merupakan suatu usaha untuk mengintegrasikan pengetahuan, keterampilan, nilai atau sikap pembelajaran, serta pemikiran yang kreatif dengan menggunakan tema (Suryosubroto, 2009). Penerapan pembelajaran tematik di sekolah dasar sangat membantu, karena sesuai dengan tingkat peserta didik yang masih melihat segala sesuatu secara menyelurh atau holistik. Guru perluberikutnya, pada bidang studi tertentu (Trianto, 2011)

Menurut (Yaumi, 2012) teori Multiple Intelligences dikembangkan oleh Howard Gardner melalui bukunya yang berjudul Frames of Mind tahun 1983 yang kemudian direvisi dengan Intelligence Reframed pada tahun 1999. Dr. Howard Gardner adalah seorang pemimpin di Project Zero Harvard University. Gardner memiliki pandangan yang berbeda tentang IQ. Menurut Gardner, orang tidak memiliki satu intelejensi umum, tetapi ditandai oleh serangkaian intelejensi. Setidaknya, ada sembilan kecerdasan yang diungkapkan oleh Gardner yaitu Verbal-Linguistik, Logis-Matematis, Visual-Spasial, Jasmaniah-Kinestetik, Berirama-Musik, Intrapersonal, Interpersonal, Naturalistik, dan Eksistensial-Spiritual (Chatib dkk, 2012).

Multiple Intelligences awalnya adalah wilayah psikologi, ternyata berkembang sampai ke wilayah edukasi, bahkan telah merambah dunia profesional di perusahaanperusaan besar. Menurut Bainbrigde (Yaumi 2012) Intelligence (kecerdasan) adalah istilah yang sulit untuk didefinisikan hingga menimbulkan pemahaman yang berbedabeda di antara para ilmuwan. Dalam pengertian yang populer, kecerdasan sering didefinisikan sebagai kemampuan mental umum untuk belajar dan menerapkan pengetahuan dalam memanipulasi lingkungan, serta kemampuan untuk berpikir abstrak. Jadi dapat disimpulkan bahwa kecerdasan majemuk atau multiple ntelligences adalah beberapa kecerdasan yang meliputi mental, fisik, sosial, maupun spiritual yang digunakan sebagai landasan untuk belajar dan menerapkan pengetahuan. Jadi setiap manusia memiliki semua jenis kecerdasan tersebut, namun hanya ada beberapa kecerdasan yang dominan atau menonjol dalam diri seseorang. Bila semua kecerdasan majemuk ini ditumbuhkan, dikembangkan, dan dilibatkan dalam proses pembelajaran, maka akan sangat meningkatkan efektivitas dan hasil pembelajaran.

Multiple intelligences sendiri atau biasa disebut dengan kecerdasan majemuk adalah berbagai keterampilan dan bakat yang dimiliki siswa untuk menyelesaikan berbagai persoalan dalam pembelajaran. Gardner menemukan depalan macam kecerdasan jamak, yakni (1) kecerdasan Verbal-Linguistik, (2) Logis-Matematis, (3) Visual-Spasial, (4) Berirama-Musik, (5) Jasmaniah-Kinestetik, (6) Interpersonal, (7) Intrapersoanal, dan (8) Naturalistik (Amstrong, 2005)

Kata belajar dalam bahasa sederhana dimaknai sebagai menuju ke arah yang lebih baik dengan cara sistematis. Kata belajar berarti proses perubahan tingkah laku pada 
siswa akibat adanya interaksi antara individu dan lingkungannya melalui pengalaman dan latihan (Iskandar \& Sunendar, 2011). Sedangkan menurut (Huda 2013), pembelajaran dapat dikatakan sebagai hasil dari memori, kognisi, dan metakognisi yang berpengaruh terhadap pemahaman. Hal inilah yang sering terjadi ketika seseorang sedang belajar, dan kondisi ini juga sering terjadi dalam kehidupan sehari-hari, karena belajar merupakan proses alamiah setiap orang.

Menurut Gindis dan Miller (Yaumi 2012) aktivitas pembelajaran merujuk pada sistem pendidikan dalam memfasilitasi peserta didik untuk menjadi agen perubahan melalui pengalaman, pengetahuan, keterampilan, dan kemampuan yang dilakukannya sendiri serta memperoleh metode untuk belajar mandiri. Dengan demikian, yang dimaksud dengan aktivitas pembelajaran adalah aktivitas atau kegiatan apa saja dari suatu individu yang dikelola dengan maksud untuk memperbaiki keterampilan, pengetahuan, dan kompetensi.

Sebagaimana teridentifikasi dari upaya inovatif dan kreatif di bidang pendidikan, banyak faktor yang mempengaruhi kualitas suatu program pendidikan diantaranya seperti kualitas siswa, kualitas guru, kualitas dan ketersediaan bahan ajar, kurikulum, fasilitas dan sarana, pengelolaan dan sebagainya. Sebagai salah satu komponen dalam pendidikan, bahan ajar dalam berbagai bentuk dan jenisnya merupakan salah satu faktor yang berpengaruh terhadap mutu pendidikan. Dalam sudut pandang teknologi pendidikan, bahan ajar dalam berbagai bentuknya dikategorikan sebagai bagian dari media pembelajaran. Maka dapat disimpulkan bahwa tujuan penelitian ini adalah untuk mengetahui pengaruh pembelajaran tematik dan multiple intellegence terhadap hasil belajar siswa.

\section{B. Metode}

Penelitian ini menggunakan penelitian kuantitatif. Penelitian ini dilakukan pada mata pelajaran IPA kelas 5 pada tema tumbuhan dan hewan. Subyek pada penelitian ini adalah siswa kelas 5 di MIN 1 Kota Malang yang berjum;ah 25 siswa. Waktu penelitian ini dilaksanakan pada bulan januari-februari tahun 2017. Intrument yang digunakan untuk pengumpulan data adalah metode angket/kuesioner. Pengujian kredibilitas instrument menggunakan uji validitas dan reliabilitas instrumen. Prosedur pengumpulan data pada penelitian ini menggunakan observasi, angket / kuesioner dan dokumentasi. Tehnik analisis data penelitian ini menggunakan analisis regresi linier berganda, yang berfungsi untuk menganalisis pengaruh suatu variabel bebas terhadap suatu variabel terikat. terhadap kinerja digunakan teknik analisis regresi linier berganda. Analisis linier berganda digunakan untuk meramalkan bagaimana keadaan (naik turunnya) variabel dependen, bila dua atau lebih variabel independen sebagai faktor prediktor dimanipulasi (Sugiyono, 2012). 


\section{Hasil dan Pembahasan}

\section{Pengaruh Pembelajaran Tematik Integratif Berbasis Multiple Intelligence Siswa Pada Tema Tumbuhan Dan Hewan DI MIN 1 Malang}

Hasil analisis yang pertama adalah untuk menguji hipotesis pertama, atau mengetahui apakah terdapat pengaruh antara varibel pembelajaran tematik berbasis multiple intelligence siswa pada tema tumbuhan dan hewan, jika terdapat pengaruh apakah positif dan signifikan atau tidak. Besarnya pengaruh dapat diketahui dari hasil analisis regresi yang ditunjukkan oleh nilai Standardized Coefficients Beta. Jika nilai Standardized Coefficients Beta menunjukkan nilai yang positif, maka pengaruhnya adalah positif, begitu pula sebaliknya. Sedangkan signifikansi dapat diperoleh dari nilai sig ataupun dengan membandingkan nilai $t$ tabel dengan $t$ hitung. Berikut hasil analisis uji hipotesis pertama tentang pengaruh pembelajaran tematik berbasis multiple intelligence siswa pada tema tumbuhan dan hewan.

Tabel 1. Hasil Uji Hipotesis 1

\begin{tabular}{|c|c|c|c|c|c|c|c|c|}
\hline \multicolumn{9}{|c|}{ Coefficients $^{\mathrm{a}}$} \\
\hline \multirow{2}{*}{\multicolumn{2}{|c|}{ Model }} & \multicolumn{2}{|c|}{$\begin{array}{l}\text { Unstandardized } \\
\text { Coefficients }\end{array}$} & \multirow{2}{*}{$\begin{array}{c}\begin{array}{c}\text { Standardized } \\
\text { Coefficients }\end{array} \\
\text { Beta }\end{array}$} & \multirow[t]{2}{*}{$\mathrm{t}$} & \multirow[t]{2}{*}{ Sig. } & \multicolumn{2}{|c|}{ Collinearity Statistics } \\
\hline & & B & $\begin{array}{l}\text { Std. } \\
\text { Error }\end{array}$ & & & & Tolerance & VIF \\
\hline 1 & $\begin{array}{l}\text { (Constan } \\
\text { t) }\end{array}$ & $\begin{array}{r}40.3 \\
98\end{array}$ & 4.900 & & 8.244 & .000 & & \\
\hline & $\mathrm{X} 1$ & .410 & .186 & .247 & 2.207 & .030. & 1.000 & 1.000 \\
\hline $\mathrm{Va}$ & $\begin{array}{l}\text { Dep } \\
\text { able:Y }\end{array}$ & dent & & & & & & \\
\hline
\end{tabular}

Berdasarkan tabel diatas, terlihat nilai Standardized Coefficients Beta adalah 0,247 (positif). Ini menunjukkan bahwa X1 (pembelajaran tematik) berpengaruh positif terhadap multiple intelegence. Artinya adalah jika metode pemeblajran tematik meningkat satu satuan, maka multiple intelegence meningkat sebesar 0,247 atau 24,7 \%. Tingkat signifikansi yang ditunjukkan adalah sebesar 0,30. Nilai ini lebih besar dibanding 0,05. Jika dilihat menurut analisis t-hitung dengan t-tabel, maka t-hitung sebesar 2, 207 > dari t-tabel $(1,666)$ sehingga dapat dinyatakan bahwa kepemimpinan kepala sekolah berpengaruh signifikan terhadap kinerja guru. Dengan kata lain bahwa hipotesis yang menyatakan pemeblajaran tematik berpengaruh positif dan signifikan terhadap multiple intelegence diterima.Besarnya variabel pemeblajran tematik dapat menjelaskan multiple intelegence, ditunjukkan oleh nilai $R^{2}$. Berikut tabel hasil koefisien determinasi dari hasil analisis data. 
Tabel 2. Hasil tabel koefisien determinasi

\begin{tabular}{|l|r|r|r|r|r|}
\hline Model Summary \\
\hline Model & $\mathrm{R}$ & R Square & $\begin{array}{c}\text { Adjusted R } \\
\text { Square }\end{array}$ & $\begin{array}{c}\text { Std. Error of } \\
\text { the Estimate }\end{array}$ & $\begin{array}{c}\text { Durbin- } \\
\text { Watson }\end{array}$ \\
\hline 1 & $.247^{\mathrm{a}}$ & .061 & .048 & 4.86119 & 1.231 \\
\hline
\end{tabular}

a. Predictors: (Constant), X1

b. Dependent Variable: Y

Berdasarkan tabel tersebut, nilai yang ditunjukkan oleh R Square adalah 0,061, artinya adalah pembelajaran tematik dapat menjelaskan multiple intelegence sebesar $6,1 \%$.

\section{Pengaruh pemebelajaran tematik terhadap hasil belajar}

Hipotesis kedua menyatakan menyatakan bahwa pemebelajaran tematik berpengaruh positif dan signifikan terhadap hasil belajar siswa. Berikut hasil dari uji hipotesis kedua:

Tabel 3 Hasil uji hipotesis

Coefficients $^{\mathbf{a}}$

\begin{tabular}{|c|c|c|c|c|c|c|}
\hline \multirow{2}{*}{\multicolumn{2}{|c|}{ Model }} & \multicolumn{2}{|c|}{$\begin{array}{l}\text { Unstandardized } \\
\text { Coefficients }\end{array}$} & \multirow{2}{*}{$\begin{array}{c}\begin{array}{c}\text { Standardized } \\
\text { Coefficients }\end{array} \\
\text { Beta }\end{array}$} & \multirow[b]{2}{*}{$\mathrm{t}$} & \multirow[b]{2}{*}{ Sig. } \\
\hline & & B & Std. Error & & & \\
\hline \multirow[t]{2}{*}{1} & (Constant) & 34.338 & 4.112 & & 8.351 & .000 \\
\hline & $\mathrm{X} 2$ & .424 & .103 & .430 & 4.120 & .000 \\
\hline
\end{tabular}

a. Dependent Variable: Y

Berdasarkan tabel tersebut terlihat bahwa nilai Standardized Coefficients Beta menunjukkan angka 0,430 dan bernilai positif. Hal ini berarti bahwa variabel pemebelajaran tematik berpengaruh secara positif sebesar 0,430. Jika hasil belajar meningkat sebesar 1 satuan maka lingkungan kerja meningkat sebesar 0,430 satuan atau 43\%. Nilai signifikansi menunjukkan nilai sebesar 0,000 atau lebih kecil dari 0,05. Jika dilihat dari nilai t-hitung yaitu sebesar 4.120, nilai ini lebih besar dari nilai t-tabel $(1,666)$. Dengan mempertimbangkan kedua criteria signifikansi tersebut, maka pengaruh pemebelajaran tematik adalah signifikan terhadap hasil belajar siswa. Atau dapat dikatakan bahwa hipotesis kedua diterima. Pemebelajaran tematik berpengaruh positif dan signifikan terhadap hasil belajar siswa Besarnya pemebelajaran tematik 
dapat menjelaskan hasil belajar siswa, ditunjukkan oleh nilai R Square atau koefisien determinasi. Berikut tabel hasil koefisien determinasi:

Tabel 4. Hasil Koefisien Determinasi

\begin{tabular}{|l|r|r|r|r|r|}
\hline \multicolumn{7}{|c|}{ Model Summary $^{\text {b }}$} \\
Model & \multicolumn{1}{|c|}{ R } & R Square & $\begin{array}{c}\text { Adjusted R } \\
\text { Square }\end{array}$ & $\begin{array}{l}\text { Std. Error of } \\
\text { the Estimate }\end{array}$ & $\begin{array}{l}\text { Durbin- } \\
\text { Watson }\end{array}$ \\
\hline 1 & $.430^{\mathrm{a}}$ & .185 & .174 & 4.53014 & 1.477 \\
\hline
\end{tabular}

a. Predictors: (Constant), X2

b. Dependent Variable: Y

Berdasarkan data tabel diatas terlihat bahwa 0,185 , sehingga pemebelajaran tematik dapat menjelaskan hasil belajar sebesar $18,5 \%$.

\section{Pengaruh multiple intelegence terhadap hasil belajar siswa}

Hipotesis ketiga menyatakan bahwa multiple intelegence berpengaruh positif dan signifikan terhadap hasil belajar siswa. Berikut hasil uji hipotesis yang ketiga:

Tabel 5. Hasil uji hipotesis

Coefficients $^{\mathrm{a}}$

\begin{tabular}{|c|c|c|c|c|c|}
\hline \multirow[b]{2}{*}{ Model } & \multicolumn{2}{|c|}{$\begin{array}{l}\text { Unstandardized } \\
\text { Coefficients }\end{array}$} & $\begin{array}{l}\text { Standardized } \\
\text { Coefficients }\end{array}$ & \multirow[b]{2}{*}{$\mathrm{t}$} & \multirow[b]{2}{*}{ Sig. } \\
\hline & B & Std. Error & Beta & & \\
\hline (Constant) & 35.634 & 4.147 & & 8.592 & .000 \\
\hline X3 & .445 & .118 & .399 & 3.770 & .000 \\
\hline
\end{tabular}

a. Dependent Variable: Y

Berdasarkan tabel diatas, terlihat bahwa Standardized Coefficients Beta menunjukkan angka 0,399 dan bernilai positif. Berarti bahwa pengaruh variabel multiple intelegence berpengaruh secara positif terhadap hasil belajar siswa sebesar 39\%. Nilai t-hitung menunjukkan angka 3,770 dengan signifikansi 0,000. t-hitung yang dihasilkan > daripada t-tabel $(1,666)$, dan signifikansi $<0,05$, sehingga pengaruh variabel multiple intelegence adalah signifikan terhadap hasil belajar siswa. Dengan kata lain bahwa, menurut uji hipotesis, dapat dikatakan hipotesis yang menyatakan bahwa terdapat pengaruh yang positif dan sgnifikan antara multiple intelegence dengan hasil belajar siswa diterima. Seberapa besar multiple intelegence dapat menjelaskan hasil belajar siswa, dapat dilihat dari tabel berkut: 
Tabel 6. Hasil Koefisien Determinasi

Model Summary ${ }^{b}$

\begin{tabular}{|l|r|r|r|r|r|}
\hline Model & \multicolumn{1}{|c|}{$\mathrm{R}$} & R Square & $\begin{array}{c}\text { Adjusted R } \\
\text { Square }\end{array}$ & $\begin{array}{c}\text { Std. Error of } \\
\text { the Estimate }\end{array}$ & $\begin{array}{c}\text { Durbin- } \\
\text { Watson }\end{array}$ \\
\hline 1 & $.399^{\mathrm{a}}$ & .159 & .148 & 4.59968 & 1.494 \\
\hline
\end{tabular}

a. Predictors: (Constant), X3

b. Dependent Variable: Y

Nilai R Square adalah sebesar 0,159, menunjukkan bahwa variabel multiple intelegence dapat menjelaskan variabel hasil belajar siswa sebesar $15 \%$.

\section{Efektivitas Pembelajaran Tematik Integratif Berbasis Multiple Intelligence Dan Hasil belajar Siswa Pada Tema Tumbuhan Dan Hewan}

Selain secara parsial, penelitian ini juga menguji apakah ketiga variabel pemebelajaran tematik integratife dan multiple intelegence dapat mempengaruhi secara bersama-sama terhadap hasil belajar siswa. Berikut hasil uji hipotesis yang menganalisis pengaruh secara simultan variabel tersebut:

Tabel 7. Hasil Uji hipotesis Simultan

ANOVA $^{b}$

\begin{tabular}{|c|c|c|c|c|c|c|}
\hline \multicolumn{2}{|c|}{ Model } & $\begin{array}{l}\text { Sum of } \\
\text { Squares }\end{array}$ & df & Mean Square & $\mathrm{F}$ & Sig. \\
\hline \multirow[t]{3}{*}{1} & Regression & 447.984 & 3 & 149.328 & 7.573 & $.000^{\circ}$ \\
\hline & Residual & 1439.445 & 73 & 19.718 & & \\
\hline & Total & 1887.429 & 76 & & & \\
\hline
\end{tabular}

a. Predictors: (Constant), X3, X1, X2

b. Dependent Variable: Y

Tingkat kesignifikansian kedia variabel, dalam hal ini pemebelajaran tematik integratife dan multiple intelegence dapat mempengaruhi secara bersama-sama terhadap hasil belajar siswa dapat dilihat dari nilai signifikansi dan nilai hitung F. Jika signifikansi lebih keci dari 0,05 maka dipastikan berpengaruh secara simultan. Jika $\mathrm{F}$ hitung lebih besar dari $\mathrm{F}$ tabel maka juga dipastikan adanya pengaruh signifikan. Berdasarkan hasil analisis ditemukan bahwa nilai sig $(0,000)<$ daripada 0,005 . Nilai $F$ tabel $(2,73)<$ nilai F hitung $(7,573)$. Dapat ditarik kesimpulan bahwa secara simultan ketiga 


\section{Simpulan}

Kesimpulan pada penelitian ini adalah terdapat pengaruh yang signifikan antara pembelajaran tematik integratif dan multiple intellegence dalam meningkatkan hasil belajar siswa. Sara bagi peniliti selanjutnya diharapkan ada pembuatan metode yang serupa guna memperkaya hasanah metode pembelajaran tematik integratife dengan mengembangkannya pada pembelajaran berbasis multiple intelegence

\section{Daftar Rujukan}

Armstrong, Thomas, (2005), Sekolah Para Juara. Bandung : Kaifa

Chatib, Munif dan Alamsyah Said. 2012. Sekolah Anak-Anak Juara : Berbasis Kecerdasan Jamak dan Pendidikan Berkeadilan. Bandung : Kaifa

Huda, Miftahul, (2013) Model-model Pengajaran dan Pembelajaran. Yogyakarta : Pustaka Pelajar.

Iskandarwassid dan Dadang Sunendar, (2011) Strategi Pembelajaran Bahasa. Bandung : PT. Remaja Rosdakarya

Sugiyono, (2001), Metode Penelitian Administrasi, Cetakan kedelapan Bandung: Alfabeta

Suryosubroto. (2009). Proses Belajar Mengajar Di Sekolah. Jakarta: PT Rineka Cipta

Trianto. (2011). Model Pembelajaran Terpadu. Jakarta: Bumi Aksara

Yaumi, Muhammad, (2012), Pembelajaran Berbasis Multiple Intelligences. Jakarta: Dian Rakyat 